(C) 2020 Sbruieva, Boychenko. This article is distributed under the terms of CC Attribution-Share Alike 4.0 International as described at https://creative commons.org/licenses/by-sa/4.0

UDC: 378.4:37.013.74:005.52

\title{
SOCIETAL DIMENSION OF DOCTORAL EDUCATION IN THE EUROPEAN HIGHER EDUCATION AREA: PRIORITIES AND TRENDS
}

\author{
Alina Sbruieva \\ DSc in Education, Professor \\ Sumy State Pedagogical University Named After A. S. Makarenko, Sumy, Ukraine \\ https://orcid.org//0000-0002-1910-0138, email: sbruieva@gmail.com \\ Maryna Boichenko \\ DSc in Education, Associate Professor \\ Sumy State Pedagogical University Named After A. S. Makarenko, Sumy, Ukraine \\ https://orcid.org//0000-0002-0543-8832, email: marinaver18@gmail.com
}

The article identifies trends in the societal dimension of doctoral training as a cycle of higher education in the EHEA. The use of the appropriate research methods allowed to characterise the essence of the societal dimension of higher education in the Bologna reform documents; to identify the specificity of the societal dimension of doctoral training within the framework of the Salzburg process, which outlines priorities for reforming doctoral training at the EHEA; to find out current trends in the development of the societal dimension of doctoral training in the EHEA and the ERA.

It is shown that the most significant are the following trends in the development of the studied phenomenon: taking into account in the process of development and realisation of $\mathrm{PhD}$ programs the needs for productive employment of young scientists; intensification of cooperation of the University with a wide range of stakeholders in the formation of professional and transversal competences and personal qualities of PhD students; development of open educational and scientific spaces (inter-university, national, international), including educational, scientific and social resources, which not only give young scientists new opportunities to implement their own scientific projects, but also require qualified and competent participation in the further development of the content of such space; structural and cultural changes in approaches to the organisation of doctoral training (introduction of structured doctoral programs and collective guidance); transformation of the University into a friendly to PhD-students ecosystem, which implies their full participation in all spheres of the university life: educational, scientific, innovative, and social. 
Key words: higher education, doctoral training, European Higher Education Area, societal dimension, reform, development trends, open educational space.

У статті Визначено тенденції розВитку сочіального Виміру докторсъкоӥ підготовки як цикку Вищої освіти в ЄПВО. Використання Відповідних методів дослідження дозволило схарактеризувати сутність соціального виміру вищої освіти $в$ документах Болонськоӥ реформи; Визначити специфріку сочіального Виміру докторської підготовки в межах Зальцбургського процесу, що визначає пріоритети реформування докторської підготовки в ЄПВО; з'ясувати сучасні тенденції розвитку сочіального виміру докторської підготовки в ЄПВО та ЄДП.

Показано, що найбільи значущими є такі тенденції розвитку досліджуваного явища: урахування $в$ процесі розробки й реалізачії докторських програм потреб ефективного працевлаштування молодих учених; активізація співпраці університету з широким колом стейкхолдерів у формуванні професійних $і$ трансверсальних компетентностей та особистісних якостей аспірантів; розвиток відкритих освітніх і наукових просторів (міжвузівсъких, національних, міжнародних), зокрема освітніх, наукових та сочіальних ресурсів, які не лише дають молодим ученим нові можливості для реалізаціі власних наукових проєктів, але й вимагають кВаліфікованої та компетентної участі $b$ подальшій розробці змісту такого простору; структурні та культурні зміни підходів до організачіӥ докторської підготовки (упровадження структурованих докторських програм і колективне керівництво); перетворення університету на дружню для аспірантів екосистему, що передбачає їх повну участь у всіх сфрерах життя університету: навчальній, науковій, інноваційній та соцуіальній.

Киючові слова: вища освіта, докторська підготовка, європейський простір Вищої освіти, суспільий вимір, реформа, тенденціӥ розвитку, відкритий осВітній простір.

Introduction. The relevance of doctoral $(\mathrm{PhD})$ education reforming in the European higher education area (EHEA) is due both to external - social factors (development of a knowledge society in which new knowledge, acquired through scientific research, becomes the leading driving force of the social progress) and internal - academic (transformation of doctoral training in the third cycle of higher education in the context of the Bologna process). Due to the factors mentioned above, doctoral training has acquired the status of the third - doctoral cycle of higher education and is undergoing systemic changes within the EHEA and, according to the European model, in many other regions of the world, covering all aspects of the research process. The goals and objectives of $\mathrm{PhD}$ training have undergone significant transformations within the EHEA, as well as principles and structure of the educational process organisation, the methods and criteria for attracting $\mathrm{PhD}$ applicants, criteria for determining and methods of checking the quality of results have been updated; new requirements for supervisors and universities-providers of scientific and educational programs have been developed. 
This study is focused on the societal dimension of doctoral education reforms, the responsibility for which is increasingly recognised by the European states, universities and academic community within the EHEA. This statement can be confirmed by the discussion of this issue at conferences and thematic workshops of the specialised structure of the European University Association - the Council for Doctoral Education (EUA-CDE), whose activities are considered an essential factor in institutionalising the societal dimension of doctoral training in the EHEA. Systematisation and generalisation of analytical and information materials of EUA-CDE, other international organisations specialising in the study and lobbying of professional and social interests and needs of young scientists (European Science Foundation, European Council of Doctoral Candidates and Junior Researchers, League of European Research Universities) provide grounds for generalisation of the positive experience and identification of trends in the societal dimension development of the studied educational and scientific phenomenon.

The study aims to clarify the nature, regulations and trends in the development of the societal dimension of doctoral training as a cycle of higher education in the EHEA.

Methodology. Realisation of the outlined goal requires the use of several groups of research methods: general scientific (analysis, synthesis, comparison, generalisation, systematisation, which made it possible to clarify the theoretical approaches underlying development of the phenomenon under study); specific scientific (the content analysis method, which allowed to characterise the state of development of the specified issue in domestic and foreign scientific thought; the method of diachronic-comparative analysis, which allowed to characterise genesis of the Bologna subjects cooperation in the formation of societal dimension of doctoral training and the method of synchronous-comparative analysis, which helped to identify trends in the phenomenon under study in modern conditions, the method of structural-logical analysis of supranational organisations and research projects in the field of reforming doctoral education in the EHEA, which allowed to outline organisational and content-procedural foundations of the studied phenomenon; empirical methods (analysis of the international organisations documents and international projects on the societal dimension of higher education).

Results and discussion. International cooperation in the field of doctoral education reform in the context of the EHEA development has been normatively reinforced in the Berlin Communiqué (2003) of the Bologna Process, which considers doctoral training as the third cycle of higher education. Since then, the collective members of the BFUG, united in E-4, and, above all, the European University Association (EUA), have applied joint effort to reorganise doctoral programs in the EHEA frequently. The collaboration of the European academic community in the framework of the EUA project "Doctoral Programs for the European Knowledge Society" (EUA, 2005) resulted in the adoption at its final conference in Salzburg in 2005 of the principles of doctoral education, which were later tentatively called "Salzburg I" (Bologna Seminar, 2005). The structural-logical analysis of these principles proves that the vast majority of them are relevant not only to the tasks of quality assurance but also to the societal dimension of doctoral training. 
It should be noted that doctoral training is directly related to both the EHEA and the European Research Area (ERA). Therefore, necessary for our study is adoption in 2005 by the European Commission of the "The European Charter for Researchers. The Code of Conduct for the Recruitment of Researchers". The analysis of this document allows us to state that it fully covers the social guarantees that must be provided to PhD applicants by the priorities set out in the ERA. In particular, this document includes "General principles and requirements for employers and organisations that fund researchers". Next, we would like to quote the formulation and interpretation of the principles that, in our opinion, best highlight the possibilities of ensuring the societal dimension of doctoral training:

Recognition of the profession. All scientists who have decided to build their careers in science and research must be recognised as professionals and treated accordingly. It should be applied at the beginning of the scientific career, in particular, at the postgraduate stage, and should cover all levels, regardless of their classification at the national level (for example, assistant, graduate student, doctoral student, postdoc, civil servant).

Non-discrimination. Employers and/or research funding organisations should never discriminate against researchers based on gender, age, ethnicity, nationality or social affiliation, religion or belief, sexual orientation, language, disability, political views, or socio-economic status.

Working conditions. Employers and/or funders must ensure that working conditions for researchers, including researchers with disabilities, are sufficiently flexible. Efforts should be made to provide working conditions that allow researchers, both women and men, to combine family and work, childcare and career development.

Stability and continuity of employment. Employers and/or funders should strive to ensure that instability of employment contracts does not adversely affect the researchers' achievements and, as far as possible, contribute to improving the stable employment of researchers, adhering to the principles and deadlines set by the EU Directive on fixed-term work.

Funding and salaries. Employers and/or funders must provide researchers with fair and attractive funding and/or wage conditions, as well as adequate and equitable social security (including sickness and parental benefits, pension rights and unemployment benefits) following applicable national legislation, national and sectoral agreements between employers and trade unions. These conditions should apply to all researchers at different stages of career development, including young scientists, according to their legal status, efficiency and level of qualifications and/or job responsibilities.

Gender balance. Employers and/or funders should strive to ensure a representative gender balance at all job levels, including the level of supervisors and management positions. Gender balance should be based on a policy of equal opportunities in employment and the later stages of professional career development, but subject to the criteria of competence and quality (EC, 2005).

The section of the European Charter for Researchers under consideration also covers a wide range of purely professional issues: "Career Development", "Value of Mobility", "Access to Professional Training and Opportunities for Continuing Professional Development", "Access to Career Counseling", "Intellectual property 
rights", "Co-authorship", "Scientific guidance", "Teaching", "Scientists' evaluation system", "Complaints/appeals", "Participation in decision-making bodies", "Employment". It should also be noted that in addition to the requirements for employers and organisations that fund researchers, the Charter we are considering contains another section - "General Principles and Requirements to Researchers", from which this document begins. The rights and obligations contained in this section include: "Freedom of Research", "Ethical Principles", "Professional Responsibility", "Professional Attitude", "Contractual and Legal Obligations", "Accountability", "Good Practice in Research", "Dissemination and Exploration of Results", "Participation in Society", "Relations with the Supervisor", "Leadership and Management", "Continuing Professional Development" (EC, 2005).

Thus, the European Charter for Researchers highlights the agreed position of the European educational, political and academic community on the leading requirements for researchers, employers and funding organisations that have social, ethical, financial and legal dimensions. It should be noted that all these dimensions entirely apply to PhD students.

It is worth noting that both of the documents mentioned above (Salzburg I and the European Charter for Researchers) were adopted in 2005. Describing the chronology of the process of addressing the issues of the societal dimension of doctoral training by the academic and scientific community, we would like to stress that significant concentration of efforts took place after the establishment in 2008 within the EUA of an international professional network of doctoral program providers - the Council for Doctoral Education (EUA-CDE), which organises annual meetings, conferences, thematic workshops, research programs on the status and prospects development of doctoral education in Europe. As a result of the EUA-CDE representative conference in Berlin in 2010, recommendations for the development of doctoral programs (Salzburg Recommendations) were adopted, which were named traditionally "Salzburg II" (EUA-CDE, 2010). The generalisation of the principles of "Salzburg I" and recommendations of "Salzburg II", the best European experience in the field of innovative doctoral education was the basis of the EC report "Mapping Exercise on Doctoral Training in Europe "Towards a Common Approach" (2011). This report included an updated formulation of the "Principles for innovative doctoral training", which, in our opinion, very accurately reflect the existing relation-ship between the quality of research resources (material, intellectual, informational, financial, technological, organisational, time) and the quality of their results. The conclusion on the interconnectedness and interdependence of the obligations of all subjects and stakeholders of doctoral training (state, HEI, research supervisor, PhD applicant, employer (the organisation that funds research)) becomes quite unambiguous based on the results of the analysis of the content of the mentioned principles.

The next step in the development of the Salzburg Process was adoption in 2015 of EUA-CDE recommendations "Taking Salzburg Forward - Implementation and New Challenges" ("Salzburg III"), which featured special attention to the following issues: creation of transparent and open rules and procedures, in particular those related to the admission to training and certification of PhD students; support by the University of full-fledged professional development of scientific supervisors and $\mathrm{PhD}$ 
applicants; research ethics and scientific integrity of research; strengthening the importance of digitalisation (open educational, informational, scientific spaces) and globalisation of research; development of interaction of stakeholders belonging to different spheres of economy and social sphere of society in order to increase the level of readiness of PhD students for employment and successful career, for professional mobility in the national and international markets of highly qualified labor resources (EUA, 2016).

Comprehensive coverage of the research problem - the societal dimension of doctoral training in EHEA requires not only genetic and structural-logical analysis of numerous documents of supranational organisations that are collective subjects of the Bologna process, but also clarification of current trends in the process. This clarification is based on the systematisation and generalisation of the views of the academic and scientific community, other stakeholders, presented in the materials of the EUA (2015), ESF (2017), LERU (2014).

Thus, the current trends in the development of the societal dimension of doctoral training in the EHEA are as follows.

1. The attitude to doctoral training as a joint social responsibility of all its subjects, which include, not least, PhD students. The manifestation of such a responsibility is, first of all, the involvement of PhD applicants in the study of the issues related to the tasks of sustainable development of society. The reason for this trend is the University's awareness of its responsibility for solving current global problems of humanity and increasing attention to them in three leading areas that are vital for sustainable development: economy, social sphere and environment. An important manifestation of this trend is the introduction of interdisciplinary and intersectoral research programs aimed at the holistic solution of problems of common interest and "common good" of humanity (Georghiou, 2019). It is worth mentioning that standardisation of the interdisciplinary doctoral programs has been the subject of special attention at the present stage of reforming higher education in Ukraine, which is reflected in the new version of the Law of Ukraine "On Higher Education".

2. The actualisation of the tasks of PhD programs graduates' productive employment. Research carried out within the framework of a large-scale project of the European Science Foundation (ESF) "Science Connect" (2011-2017) shows a high demand for graduates of $\mathrm{PhD}$ programs who have obtained a scientific degree. Evidence of the validity of this judgment is the fact that $95 \%$ of $\mathrm{PhD}$ graduates are employed within the first four months after graduation. Among employed graduates of $\mathrm{PhD}$ programs, $80 \%$ continue their research activities, more than $60 \%$ work in the academic sphere (46\% of them in universities), about $40 \%$ - in the non-academic sphere $(17 \%$ - in business structures, $8 \%$ - in government, $6 \%$ - in practical medi-cine). A study of the gender dimension of the young researchers' employment by ESF analysts has found that men with PhD degrees are slightly more employed in such areas as science, engineering and agriculture, while women are more employed in such areas as medicine, social sciences and humanities; approximately the same proportion of men and women work as senior researchers and research administrators in relevant fields (ESF, 2017). According to the survey of employers conducted by the ESF on the impact of PhD professionals on the quality of production tasks, $75 \%$ of respondents believe that $\mathrm{PhD}$ professionals have a significant positive impact on the 
quality of production processes, and $20 \%$ believe that loss of such professionals can have catastrophic consequences for production (Metcalfe, 2019).

According to the EUA-CDE survey in 2018, the study of the current state and future employment prospects of young scientists is one of the most pressing issues for all EHEA countries (EUA-CDE, 2018). However, the analysis of statistical data provided on the website of the State Statistics Service of Ukraine casts doubt on this statement, at least for our country, since, starting with the national report for 2015, state statistical observations on the number of doctors and candidates of sciences in Ukraine's economy have been abolished (State Statistics Service, 2019). Some data in the context of our problem are found in the study of Ukrainian scientists S. Zhabin and O. Kazmina (2016), which describes the social status and working conditions of young scientists at the National Academy of Sciences of Ukraine. In particular, the researchers surveyed the desire for future employment of PhD graduates of the NAS of Ukraine, as a result of which they obtained the following data: 48,5\% - NAS of Ukraine; $16,5 \%$ branch research institutes; $28,9 \%$ - HEIs; $26,8 \%$ - business; $9,3 \%$ - civil service; $42,3 \%$ abroad. Most striking is the particular indicator for our country $-42,3 \%$ of respondents who want to go abroad for career development, which means dissatisfaction of young people with many aspects of their lives, including the social status of a young scientist. At the same time, despite all the existing socio-economic and socio-political problems, we see an indicator of $48,5 \%$ of young scientists who link their professional future with Ukrainian science (Zhabin \& Kazmina, 2016).

3. Increasing attention of the academic community to the development of PhD students of transversal socially significant competences and personal qualities, which are considered as an essential factor in the successful employment of young scien-tists. These competences and personal qualities include, above all, problem-solving skills, teamwork, leadership, intellectual mobility, presentation of their research in a form accessible to professional and general public, interpersonal communication; project management; entrepreneurship, innovation, enthusiasm, responsibility; ability and tendency to self-improvement, ability to work in different professional, cultural and ethnic environments; employability. (Horbunova, 2016; Metcalfe, 2019). It should be noted that transversal competences and personal qualities are considered within the EHEA as integral components of the framework standards of doctoral training and matrix competences of PhDs developed on their basis (Lutz, 2019; Horbunova, 2016).

4. The principles of doctoral training modernisation, proclaimed in the pri-mary documents of the Salzburg process include ensuring adequate funding for re-search programs of PhD applicants, which allows their successful completion. Ho-wever, according to EUA-CDE research, different EHEA countries have fundamen-tally different practices, models, funding strategies for higher education in general and doctoral research in particular, which are not always "friendly" to young resear-chers (EUA-CDE, 2018). The source of funding for doctoral research is often the state budget; other sources (according to their degree of importance) include university grants, scholarships, university employment, international grants, non-governmental (private companies, public organisations) sources (EUA-CDE, 2018, p. 20). According to "The EUA Public Funding Observatory" (EUA, 2017), EUA-CDE experts stated that while some countries continue to commit to investing public resources in higher education (e.g. Austria, Germany and Luxembourg), others, such as Ireland, Spain and several 
countries in South-Eastern and Central Europe, are experiencing sharp cuts in funding. Such divergent trajectories of educational policy support and even expand the qualitative differences between national systems in the EHEA and the ERA (EUACDE, 2018, p. 21). Underfunding of doctoral research is also typical for Ukraine. Proof of this state of affairs is, in particular, the sharp decline in the number of graduate and doctoral students in recent years. According to the Statistical Yearbook of Ukraine for 2018 , the number of graduate students in the country decreased from 2013 to 2018 by $23 \%$; the number of doctoral students - by 33\%. According to the State Agency for Science, Innovation and Informatisation, in 2014 Ukraine had the lowest ratio of the number of scientists to the number of econo-mically active population among European countries: the saturation of scientific personnel in Ukraine is 3,7 people per 1 thousand economically active population, while in Finland this figure is 15,4; Japan 11; USA - 9,7; Germany - 11,5; Czech Republic - 8,8; Poland - 6,4; on average in the EU - 9,2 (State Agency for Science, Innovation and Informatization, 2014). According to the study (Zhabin \& Kazmina, 2016), the level of social needs of PhD students, the quality of equipment for their workplace is significantly deteriorating. The main factors causing the crisis in doctoral training funding in Ukraine include both deep socio-economic and political crisis and the lack of a clear state strategy to support young researchers, taking into account their professional and social needs.

5. Development of open educational and scientific spaces. We would like to note the growing role of social networks in the formation of open educational and scientific spaces and the importance of creating personal blogs of famous scientists, which allow young people to informally communicate with the general scientific community and express their views within the proposed or self-initiated scientific problem. The distribution of PhD graduates' networks (e.g. Linkedin) is actualised, which are useful in expanding professional contacts, further employment and profe-ssional development of persons obtaining a PhD degree (Ritter, 2017). In the context of considering the societal dimension of this aspect of the studied issue, we empha-sise intensification of the struggle of the academic community against multinational profitable publishing houses, which monopolise the most prestigious international scientific journals and demand money for access to scientific information that is unaffordable for young scientists. We believe that increasing the level of availability of relevant scientific information is a matter of state scientific policy, concerted efforts of the broad scientific community. An essential example of the positive result of the joint efforts of the German scientific community was signing an agreement between the National Conference of German University Rectors (Hochschulrektorenkonferenz) and one of the largest multinational publishing companies Springer Nature (formed in 2015 by merging Springer, Palgrave, Adis and Macmillan), according to which the publishing company provides from 2020 to 2022 open access to online reading of Springer Nature journals and online publications in them for scientists and students of German universities and research institutions. In current conditions, this agreement is considered the largest in the world. Its signing is the result of active cooperation of universities, libraries, research institutions (notably the Max Planck Society) within the national project (Projekt DEAL) and can serve as an example to follow for other countries (World's largest, 2020).

6. Transformation of thesis supervision models: from the master-apprentice 
model, in which research is carried out in a particular field of knowledge under the individual guidance of a research mentor (scientific father/mother), who carries personal scientific and moral responsibility for the formation of a young scientist, his adherence to the norms of scientific ethics and the quality of his dissertation research, to models of group leadership (collaborative cohort model), which involves research in a particular field of knowledge under the guidance of a group of people, united by common scientific interests, and the dissertation house model. The new models involve a PhD student collaborating with several supervisors in an interdisciplinary study in which each researcher is responsible for a specific subject area and interacts with others to achieve a common result. The collaborative scientific guidance diversifies the applicant's scientific contacts, but complicates his reporting, requires from all representatives of the so-called "dissertation house" and, in particular, from the young researcher, responsible interaction and ethics of scientific relations (EUA, 2016; Barnett, Harris \& Mulvany, 2017; Bitusikova, 2009).

7. Introduction of system strategies for transforming the University into a young scientist's friendly inclusive ecosystem, which provides for its full participation in the educational, scientific, innovative and social life of the University. The dimensions as mentioned above of the University constitute its mission in modern society. The inclusive social dimension of the university ecosystem envisages PhD applicants' involvement in a wide variety of internal and external institutional programs aimed at meeting the social needs of the university and local communities' members. The PhD student in this context is an equal member of these communities, which performs not only the functions of the subject of social programs but also their object; the need for material well-being, physical and mental health, further employment, international mobility are in the centre of constant attention of the academic community and special (social, career, international cooperation) services of the University (Deem, 2019).

Conclusions. The societal dimension of higher education, interpreted from the first steps of the Bologna Process as ensuring the right to quality higher education for all, has become one of the leading tasks and conditions of full EHEA development during twenty years of international cooperation in higher education reforming. Evidence of the legitimacy of this statement is the provisions of the primary documents of the Bologna Process (communiqué and declarations of the BFUG summits 2001-2018), which formulate the commitments of the member states of the Bologna Process in the research area. The European Social Charter, which recognises, among many others, the right to vocational training and social protection against any discrimination, has become a federal guideline for defining the essence of the societal dimension of higher education in the EHEA.

With the transformation of doctoral training into the third cycle of higher education within the EHEA, strategies for its reforming have been developed by the general priorities of the Bologna Process and the specifics of this cycle. The set of documents on doctoral reform, which is the result of active cooperation of the European educational, political, academic and scientific communities within the so-called Salzburg process, contains indisputable confirmation of the importance and relevance of the societal dimension of reforms introduced in the third cycle of higher education. It is found out that the specifics of the societal dimension of doctoral training is due to the attitude to 
the PhD applicant as a full-fledged subject of professional (research) activities, which results in fundamentally new approaches to determining not only his rights (civil, social) but also responsibilities, namely for the quality of the process and the result of educational and scientific activities along with other stakeholders.

The current trends in ensuring the societal dimension of doctoral training in the EHEA include: strengthening the responsibility of the scientific community, including $\mathrm{PhD}$ graduates, for solving socially significant problems aimed at ensuring sustainable development of society; systematic consideration in the development and implementation of educational and scientific programs of doctoral training of the needs of productive employment of young scientists, which involves active cooperation of the University with a wide range of stakeholders in the formation of their professional and transversal competences and personal qualities; development of open educational and scientific spaces, in particular through active interaction of national scientific and academic communities with transnational publishing companies (DEAL project in Germany), which significantly facilitates the access of young scientists to relevant scientific information and the opportunity to publish their own research; structural and cultural changes in approaches to the organisation of doctoral training (introduction of structured doctoral programs and collective scientific guidance), which significantly expands the opportunities for consultation and discussion of the process and results of research; transformation of the University into a friendly to PhD-student ecosystem, which provides for his/her full participation in all spheres of university life: scientific, innovative, educational, social. A negative trend is the growing disparities between national higher education systems within the EHEA in terms of resources, including financial support for doctoral training.

The prospects for further research are seen in finding out the possibilities of creative use of the progressive ideas of the Salzburg process in general and ensuring the societal dimension of doctoral training in Ukraine.

\section{References:}

Barnett, J. V., Harris, R. A., \& Mulvany M. J. (2017). A comparison of best practices for doctoral training in Europe and North America. FEBS PRESS. doi:10.1002/2211-5463.12305.

Bitusikova, A. (2009) Reforming doctoral education in Europe. Academe, 95 (1). Retrieved from: http://aaup.org/AAUP/pubsres/academe/2009/JF/Feat/bitu.htm.

Bologna Seminar on Doctoral Programmes for the European Knowledge Society (Salzburg, 3-5 February 2005). Conclusions and recommendations. Retrieved from: www.eua.be/Libraries/cde/ Salzburg_Conclusions.pdf.

Deem, R. (2019). Contemporary Doctoral Education, Doctoral Researcher Wellbeing and The Public Good: a Sociological Approach. EUA-CDE Annual Meeting, 12-14 June 2019, University of Brescia, Italy.

European Commission (2005). The European Charter for Researchers. The Code of Conduct for the Recruitment of Researchers. Luxembourg: Office for Official Publications of the European Communities.

European Science Foundation (2017). Career Tracking Survey of Doctorate Holders Project Report. ESF, France, Strasbourg.

European University Association (2005). Doctoral Programmes for the European Knowledge Society. Report on the EUA Doctoral Programmes Project 2004-2005. EUA, Brussels, Belgium.

European University Association (2015). Principles and Practices for International Doctoral Education, FRINDOC project Report. EUA, Brussels, Belgium.

European University Association (2017). The EUA Public Funding Observatory. Retrieved from: https://eua.eu/resources/publications/718:eua-public-funding-observatory-2017.html. 
European University Association (2018). The EUA Public Funding Observatory. Retrieved from: https:// eua.eu/resources/publications/823:eua-public-funding-observatory-report2018.html

EUA Council for Doctoral Education (2010). Salzburg II Recommendations: European Universities' Achievements Since 2005 in Implementing the Salzburg Principles. Retrieved from: www.euacde.org/reports-publications.html.

EUA Council for Doctoral Education (2016). Doctoral education - taking Salzburg forward. Implementation and new challenges. EUA, Brussels, Belgium.

EUA Council for Doctoral Education (2018). Doctoral education in Europe today: approaches and institutional structures. By A. Hasgall, B. Saenen, L. Borrell-Damian. EUA CDE, Brussels, Belgium.

Georghiou, L. (2019). The societal dimension of doctoral education. EUA-CDE Annual Meeting, 12-14 June 2019. University of Brescia, Italy.

Horbunova, L. (2016). Key competences in the transnational educational space: Definition and implementation. Philosophy of Education, 2 (19), 97-117.

League of European Research Universities (2014). Good Practice Elements in Doctoral Training. LERU Advice Paper, No. 15.

Lutz, Ph. (2019). PhDs: vector of mobility between academia and socio-economic fields. EUA-CDE Annual Meeting, 12 -14 June 2019, University of Brescia, Italy.

Metcalfe, J. (2019). Doctoral researchers: the bridge between universities and society. The Careers Research and Advisory Centre (CRAC) Ltd., Vitae.

Ritter, M. (2017). Digitalisation of society, the role of universities and its impact on doctoral education and research. EUA-CDE Annual Meeting, 15 June 2017, Tallinn University.

State Statistics Service of Ukraine (2019). Statistical Yearbook of Ukraine for 2018. Zhytomyr: BOOK-PRINT Ltd.

State Agency for Science, Innovation and Informatisation (2014). Ukraine has the lowest number of scientists per 1,000 employees in Europe. Retrieved from: https:/ /www.kmu.gov.ua/news/ 247219007.

World's largest OA agreement signed with Springer Nature (2020, January 17). University World News. Retrieved from: https://www.universityworldnews.com/post.php?story $=20200117073909800$

Zhabin, S., \& Kazmina, O. (2016). Molodi naukovtsi: sotsialnyi stan ta umovy pratsi v Natsionalnii akademii nauk Ukrainy [Young Scientists: Social Status and Working Conditions at the National Academy of Sciences of Ukraine]. Retrieved from: https://commons.com.ua/uk/molodi-naukovciukrayini/. 